\title{
Switching from systemic steroids to high doses of ciclesonide restores the hypothalamic pituitary- adrenal axis
}

\author{
Jerzy Marczak ${ }^{1 *}$, Maciej Ciebiada², Pawe Górski \\ From EAACI International Severe Asthma Forum (ISAF 2012) \\ Gothenburg, Sweden. 11-13 October 2012
}

\section{Question}

Treatment of difficult asthma with oral corticosteroids (OCS) may suppress hypothalamic-pituitary-adrenal axis. In this study we checked if high doses of ciclesonide instead of OCS may restore the adrenal function without loss of the disease control.

\section{Methods}

In five asthmatics with poor control of the disease despite treatment with systemic corticosteroids OC were replaced with high doses of ciclesonide (1600-2400 $\mu \mathrm{g} /$ day). The pulmonary function tests (PFTs), asthma control test and the morning levels of cortisol and ACTH were measured at baseline and in 28 and 56 day of treatment.

\section{Results}

All patients improved in asthma control scores from mean value 9,4 to, 19,8 in 70 days. In four subjects FEV1 improved significantly with mean increase of up to $585 \mathrm{ml}$ in 70 days ACTH levels were normalized in 3 patients after 28 days of observation and in all patients after 56 days. Cortisol level was normalized in 3 patients after 28 days and in next two subjects after 56 days.

\section{Conclusions}

In patients with difficult to treat asthma switching from the prednisone to high doses of ciclesonide may normalize hypothalamic pituitary adrenal axis function and improves the disease control and PFTs.

'Medical University of Lodz, Poland

Full list of author information is available at the end of the article

\author{
Author details \\ ${ }^{1}$ Medical University of Lodz, Poland. ${ }^{2}$ Medical University of Lodz, Department \\ of Pneumonology and Allergy, Poland.
}

Published: 3 May 2013

doi:10.1186/2045-7022-3-S1-P27

Cite this article as: Marczak et al: Switching from systemic steroids to high doses of ciclesonide restores the hypothalamic pituitary-adrenal axis. Clinical and Translational Allergy 2013 3(Suppl 1):P27.

Submit your next manuscript to BioMed Central and take full advantage of:

- Convenient online submission

- Thorough peer review

- No space constraints or color figure charges

- Immediate publication on acceptance

- Inclusion in PubMed, CAS, Scopus and Google Scholar

- Research which is freely available for redistribution

Submit your manuscript at www.biomedcentral.com/submit
() Biomed Central 